\title{
Attenuation of carbohydrate metabolism and lipid profile by methanolic extract of Euphorbia helioscopia and improvement of beta cell function in a type 2 diabetic rat model
}

Imtiaz Mustafa ${ }^{1}$, Haseeb Anwar ${ }^{1 *}$, Shahzad Irfan ${ }^{1}$, Humaira Muzaffar ${ }^{1}$ and Muhammad Umar ljaz ${ }^{2}$

\begin{abstract}
Background: Traditional plant-based remedies prescribed to treat diabetes have shown promise in research-based setting. Current research was conducted to examine the antidiabetic and antioxidant effects of methanolic extract of a folk herbal plant Euphorbia helioscopia in a rat model of type 2 diabetes.

Methods: Diabetes was induced in male Wistar rats by administering $5 \%$ sucrose in drinking water and cafeteria diet for 8 weeks with subsequent nicotinamide and streptozotocin administration. Diabetic rats were then distributed into four individual groups ( $n=8)$; Positive control (PC; no treatment), standard control (SC; Metformin @ $10 \mathrm{mg} / \mathrm{kg}$ bw), treatment 1 (EH1, E. helioscopia methanolic extract @200 mg/kg bw) and treatment 2 (EH2, E. helioscopia methanolic extract @ $400 \mathrm{mg} / \mathrm{kg}$ bw). After 21 days of treatments, the rats were decapitated for blood collection. Serum was evaluated for antidiabetic potential, antioxidant and lipid profile, thyroid hormone, amylin, leptin, and carbohydrate metabolic enzymes. Data were analyzed statistically by one-way analysis of variance (ANOVA).

Results: Serum levels of glucagon, glucose and C-peptide were significantly $(P \leq 0.05)$ decreased in EH1 $\left(1915.33 \pm 98.26^{\mathrm{a}} \mathrm{pg} / \mathrm{ml}, 122.59 \pm 2.99^{\mathrm{a}} \mathrm{mg} / \mathrm{dl}, 277.59 \pm 28.41^{\mathrm{a}} \mathrm{pg} / \mathrm{ml}\right.$ respectively) and $\mathrm{EH} 2\left(1575.28 \pm 56.46^{\mathrm{a}} \mathrm{pg} /\right.$ $\mathrm{ml}, 106.04 \pm 5.21^{\mathrm{a}} \mathrm{mg} / \mathrm{dl}, 395.06 \pm 42.55^{\mathrm{a}} \mathrm{pg} / \mathrm{ml}$ respectively) as compared to the PC $\left(3135.78 \pm 189.46^{\mathrm{b}} \mathrm{pg} / \mathrm{ml}\right.$, $191.24 \pm 17.75^{\mathrm{b}} \mathrm{mg} / \mathrm{dl}, 671.70 \pm 109.75^{\mathrm{b}} \mathrm{pg} / \mathrm{ml}$ respectively) group. A similar trend was observed in serum insulin levels in $\mathrm{EH} 1$ and $\mathrm{EH} 2$ groups. The plant's methanolic extract effectively reduced the total oxidant status (TOS) and MDA levels in the diabetic rats and increased the total antioxidant capacity (TAC) along with an increased level of SOD, Catalase, Paraoxonase, and arylesterase. The plant extract also induced antihyperlipidemic activity and recovered the thyroid hormones, amylin, and leptin levels to normal. The activity of different carbohydrate metabolic enzymes like Pyruvate Kinase, Glucose 6 phosphate dehydrogenase, phosphofructokinase, and glucokinase has also been restored by the extract treatment.
\end{abstract}

\footnotetext{
*Correspondence: drhaseebanwar@gcuf.edu.pk

${ }^{1}$ Department of Physiology, Faculty of Life Sciences, Government College

University, Faisalabad, Pakistan

Full list of author information is available at the end of the article
}

(C) The Author(s) 2022. Open Access This article is licensed under a Creative Commons Attribution 4.0 International License, which permits use, sharing, adaptation, distribution and reproduction in any medium or format, as long as you give appropriate credit to the original author(s) and the source, provide a link to the Creative Commons licence, and indicate if changes were made. The images or other third party material in this article are included in the article's Creative Commons licence, unless indicated otherwise in a credit line to the material. If material is not included in the article's Creative Commons licence and your intended use is not permitted by statutory regulation or exceeds the permitted use, you will need to obtain permission directly from the copyright holder. To view a copy of this licence, visit http://creativecommons.org/licenses/by/4.0/. The Creative Commons Public Domain Dedication waiver (http://creativeco mmons.org/publicdomain/zero/1.0/) applies to the data made available in this article, unless otherwise stated in a credit line to the data. 
Conclusion: Current study indicates the antioxidant and antidiabetic potential of E. helioscopia methanolic extract in normalizing the lipid profile, thyroid hormones, amylin, leptin, and carbohydrate metabolism in type 2 diabetic rat model.

Keywords: Euphorbia helioscopia, Antioxidant, Methanolic extract, Antidiabetic, Carbohydrate metabolism

\section{Background}

Diabetes mellitus, one of the most common metabolic conditions causing hyperglycemia due to disruption in the metabolism of carbohydrates, proteins, and lipids induced by a relative or absolute decline in insulin secretion and insulin action [1]. The incidence of diabetes in modern society is growing gradually and becoming an epidemic. There are currently 415 million diabetic patients globally and by 2040 it is estimated to be around 642 million [2]. Pakistan has 27.4 million diabetic patients of age $\geq 20$ years estimated by the second national diabetes survey of Pakistan (NDSP-II 2016-17) at 26.3\% of diabetes prevalence $[3,4]$.

The World Health Organization (WHO) reports that about three-quarters of the population, primarily in Latin American, African and Asian countries, relies on herbal preparations in their conventional primary health care medicine system [5]. Pakistan has large biodiversity of genetic plants and, owing to inadequate access to health assistance, medicinal plants have been widely used by almost all populations [6].

Natural products continue to represent the main source of therapeutic and preventive regimens of different illnesses. The family of Euphorbiaceae contains a variety of medicinal plants possessing a wide range of different reported therapeutic effects. Euphorbia helioscopia is an annual herbaceous medicinal plant belonging to the spurge family Euphorbiaceae. It contains 24 secondary metabolites, including euphornin, euphoheliosnoid $D$, euphornin (B, C), euphoscopin (A-C, F, J), epieuphorscopin (A, B), hemistepsin, helioscopinolide (B, C), 2 alpha hydroxy helioscopinolide B, 4 5-dihydroblumentol A, guaiane lactone, icariside aglycone B2, 2' $4^{\prime} 4^{\prime}$-trihdroxy chalcone, echinatialicochalcone $(\mathrm{A}, \mathrm{B})$, galabrone and 4' 5 7-trihdroxyflavanone [7]. These secondary metabolites induce numerous pharmacological effects including vasodepressor activity, anti-inflammatory, antimicrobial activity, antioxidant, anti-tumor, and wound healing activities [8-12]. Traditionally, the plant has been used to treat a variety of pathological disorders, including skin diseases, warts, bowel parasites, migraines, and gonorrhea [13]. The medicinal plants having antioxidant and anti-inflammatory activities can reduce hyperglycemia [14]. We previously reported the in vitro antioxidant and antidiabetic activities of E. helioscopia extracts in which the methanolic extract showed maximum antidiabetic and antioxidant activity as compared to ethanolic and aqueous extracts of the plant [15]. So the present study was conducted to examine the ability of methanolic extract of E. helioscopia to modulate oxidative stress, hyperglycemia, and carbohydrate metabolism in a type 2 diabetic rat model.

\section{Methods \\ Procurement of plant}

The plant Euphorbia helioscopia was locally collected from the premises of Government College University, Faisalabad, Pakistan, from October 15, 2020, to October 30,2020 . The plant was identified by the expert Botanist (Dr. Qasim Ali) from the Department of Botany, Government College University Faisalabad, Pakistan, with a specimen voucher number, 247-bot-2020.

\section{Extract preparation}

After washing with distilled water, the plant was shade dried and grounded into a fine powder form. Two hundreds and fifty grams of this powder was soaked for $72 \mathrm{~h}$ in $1250 \mathrm{ml}$ of methanol with periodic stirring and mixing. The solution was subsequently filtered through Whatman ${ }^{\circledR}$ filter paper. The process was repeated thrice, and the final filtrates were concentrated in a rotary evaporator at $40^{\circ} \mathrm{C}$ and finally transferred into labeled petri dishes. The petri dishes were kept in an incubator at $40^{\circ} \mathrm{C}$ until dried properly. The yield of the extract was $15.7 \%$ of the dry weight of the plant powder. Thereafter the extract was stored at $4^{\circ} \mathrm{C}$ until further use.

\section{Experimental animals and induction of diabetes}

After the approval from Animal Care and Ethical Committee, Government College University Faisalabad (GCUF/ERC/2223), 48 male albino (Wistar strain) rats of age $2 \pm 1$ week, weighing $60 \pm 10 \mathrm{~g}$ were procured from the animal experimental station of Department of Physiology, Government College University, Faisalabad, Pakistan. The rats were kept in wired cages with ad libitum approach to cafeteria diet and $5 \%$ sucrose in drinking water at standard conditions (temp $=26^{\circ} \mathrm{C} \pm 2{ }^{\circ} \mathrm{C}$; light $=12 \mathrm{~h}$ light and dark cycle; ambient humidity $=40-60 \%)$. Another group of eight rats as negative control $(n=8 ; \mathrm{NC})$ were kept in the same conditions except for $5 \%$ sucrose in drinking water and cafeteria diet, during the complete duration of the experimental 
trial. The cafeteria diet contained cheese, peanuts, various biscuits, potato chips, corn chips, crackers, pizza, and various chocolates, along with a control chow diet. Any five of these cafeteria diets were given to the rats daily in surplus amounts. The foods ration was changed daily to sustain the diversity by substituting three foods with new food items. So that the rats did not get the same diets for more than two successive days at one time [16]. The cafeteria diet and $5 \%$ sucrose in drinking water were given to the rats starting from the age of $2+1$ weeks for 56 days (8weeks). After 8 weeks the rats weighing $300 \pm 20 \mathrm{~g}$, with blood glucose level $\geq 150 \mathrm{mg} / \mathrm{dl}$ were fasted overnight and administered nicotinamide (NIC; $110 \mathrm{mg} / \mathrm{kg}$ bw; ip) in normal saline [17]. After $15 \mathrm{~min}$ of the administration of nicotinamide, the dose of freshly prepared streptozotocin (STZ; $65 \mathrm{mg} / \mathrm{kg}$ bw; ip) in cold citrate buffer $(0.1 \mathrm{M}, \mathrm{pH} 4.5)$ was administered [17]. Hyperglycemia was confirmed after $72 \mathrm{~h}$ by measuring blood glucose levels using a glucometer (Glucocard 01-mini, Arkray Factory Inc., Japan) [17]. The 32 rats with blood glucose level $\geq 250 \mathrm{mg} / \mathrm{dl}$ were divided equally into the following 4 groups PC (Positive control; no treatment), SC (Standard control group; Treated with metformin $10 \mathrm{mg} /$ kg bw [18] via oral lavage), EH1 (Treatment group-I fed on CMD and plant extract dose $200 \mathrm{mg} / \mathrm{Kg} \mathrm{BW}$ via oral lavage), EH2 (Treatment group-II fed on CMD and plant extract dose $400 \mathrm{mg} / \mathrm{Kg}$ BW via oral lavage). The doses of the plant extract were followed by previous studies [19-21] on the antidiabetic potential of the methanolic extract of plants from the euphorbeacea family. Suspensions of metformin in normal saline and plant extracts in distilled water were made on daily basis. Volumes of these suspensions were calculated according to the bodyweight of each rat in the relevant group. The calculated volume of the suspension was delivered to the rats via oral lavage using an intragastric tube. No motility or toxic effects were observed in any experimental group. After the completion of 21 days of treatment, the rats were sacrificed by cervical decapitation under ether anesthesia for the collection of blood directly from the jugular vein in vacutainers without anticoagulant. Serum was isolated at $2000 \mathrm{~g}$ centrifugation for $10 \mathrm{~min}$ and kept at $-20^{\circ} \mathrm{C}$ till further analysis. Pancreas was excised and kept in $10 \%$ formalin for histopathology studies.

\section{Serum hormones levels and C-peptide}

Commercially available ELISA kits manufactured by Elabscience, USA were used to measure the serum levels of various hormones like Triiodothyronine $\left(\mathrm{fT}_{3}\right.$; $\mathrm{ng} / \mathrm{ml}$; Cat. No. E-EL-0079; Sensitivity: $0.937 \mathrm{pg} / \mathrm{ml}$; Range of Detection: $1.6-100 \mathrm{pg} / \mathrm{ml})$, Thyroxin $\left(\mathrm{fT}_{4} ; \mu \mathrm{g} /\right.$ dl; Cat. No. E-EL-0122; Sensitivity: 0.937 pg/ml; Range of Detection: $1.6-100 \mathrm{pg} / \mathrm{ml}$ ), Thyroid Stimulating
Hormone (TSH; ng/ml; Cat. No. E-EL-R0976; Sensitivity: $0.747 \mathrm{ng} / \mathrm{ml}$; Range of Detection: $1.25-80 \mathrm{ng} / \mathrm{mL}$ ), Insulin (Rat INS; ng/ml; Cat. No. E-EL-R2466; Sensitivity: $0.20 \mathrm{ng} / \mathrm{ml}$; Range of Detection: $0.309-20 \mathrm{ng} / \mathrm{ml}$;), C-peptide (Rat C-P; pg/ml; Cat No: E-EL-R3004; Sensitivity: $9.4 \mathrm{pg} / \mathrm{mL}$; Range of Detection: $15.64-1000 \mathrm{pg} /$ $\mathrm{mL}$ ), Leptin (Rat LEP; ng/ml; Cat. No. E-EL-R0528; Sensitivity: $0.11 \mathrm{ng} / \mathrm{ml}$; Range of Detection: $0.16-$ $0.92 \mathrm{ng} / \mathrm{ml}$ ), and Amylin (Rat IAPP; pg/ml; Cat. No. E-EL-R2448; Sensitivity: $37.51 \mathrm{pg} / \mathrm{ml}$; Range of Detection: $62.51-4000 \mathrm{pg} / \mathrm{ml})$. Coefficient of variation for all the kits was $<10 \%$. The manuals provided in the kits were followed for the assay procedure for all the above mentioned hormones and $\mathrm{C}$-peptide.

\section{Carbohydrate metabolic enzymes and superoxide dismutase}

Serum levels of Carbohydrate metabolic Enzymes, Pyruvate Kinase (Rat PK; ng/ml Cat. No. E-EL-R0837), Phosphofructokinase (Rat 6.PFK; ng/ml; Cat. No. E-ELR1214; Sensitivity: $0.957 \mathrm{ng} / \mathrm{mL}$; Range of Detection: 1.6-100 ng/ml), Glucose 6-Phosphate Dehydrogenase (Rat G6PD; $\mu \mathrm{lU} / \mathrm{ml}$; Cat. No. E-EL-R0428; Sensitivity: $0.11 \mathrm{ng} / \mathrm{ml}$; Range of Detection: $0.16-11 \mathrm{ng} / \mathrm{ml}$ ), and glucokinase (Rat GCK; ng/ml; Catalog No. E-EL-R0426 Sensitivity: $0.39 \mathrm{ng} / \mathrm{mL}$; Range of Detection: $0.63-41 \mathrm{ng} /$ $\mathrm{ml}$ ), and Superoxide dismutase (Rat SOD; Catalog No. E-EL-R1424; Sensitivity: $0.11 \mathrm{ng} / \mathrm{ml}$; Range of Detection: $0.16-11 \mathrm{ng} / \mathrm{ml}$ ) were analyzed by using ELISA kits manufactured by Elabscience, USA. The coefficient of variation for all the ELISA kits was $<10 \%$. The manuals provided in the ELISA kits were followed for the assay procedure for all the above-mentioned carbohydrate metabolic enzymes and superoxide dismutase.

\section{Serum lipid profile and glucose level}

Commercially available colorimetric assay kits manufactured by Sigma-Aldrich, Germany, were used for the serum levels of Total Cholesterol (Catalog Number CS0005; mg/dl; Detection range: $1-5 \mu \mathrm{g})$, Triglycerides (Catalog Number MAK266; mg/dl; Sensitivity: 2 pmole-10 nmole; Detection range: $2-10,000 \mu \mathrm{M}$ range), HDL-Cholesterol (Catalog Number MAK045; mg/dl; Detection range: $1-5 \mu \mathrm{g})$. The manuals provided in the kits were followed for the assay procedure of serum total cholesterol, serum triglycerides, and serum HDL-cholesterol level determination. Serum LDL-Cholesterol was calculated by using the Friedrick equation. Serum glucose was quantified through Bioclin ${ }^{\circledR}$ Glucose Monoreagent diagnostic kit having detection range of $2-500 \mathrm{mg} / \mathrm{dl}$ with CV\% <3.11. 


\section{Total antioxidant capacity ( $\mathrm{mmol} \mathrm{Trolox}_{\text {equiv. }} / \mathrm{L}$ )}

The method for evaluating total antioxidant capacity (TAC) in serum samples was previously defined by Nisar et al. [22]. In short, the antioxidants present in the sample bleach the ortho dianisidine color in the assay reagent. Increased antioxidant levels in the sample contribute to higher bleaching and reduced absorbance, suggesting an inverse standard curve. The Biolab ${ }^{\circledR} 310$ semi-auto analyzer was used with biochromatic wavelength modification $(660$ and $870 \mathrm{~nm})$ by calibrating Trolox standards at $1,3,5$, and $7 \mathrm{mmol} / \mathrm{L}$ concentrations. This assay had a minimum observable value of $0.19 \mathrm{mmol} / 7$ and linearity of up to $8 \mathrm{mmol}$ Trolox equivalent $/ \mathrm{l}$, with a coefficient of variance $<3 \%$ in the intra-assay.

\section{Total oxidant status (TOS; $\mu \mathrm{mol} \mathrm{H}_{2} \mathrm{O}_{2 \text { equiv. }}$ / $\mathrm{L}$ )}

The serum TOS was measured by using the technique previously adopted by Nisar et al. [22]. The standard curve was constructed from different hydrogen peroxide $\left(\mathrm{H}_{2} \mathrm{O}_{2}\right)$ concentrations and the TOS was represented as $\mu \mathrm{mol} \mathrm{H}_{2} \mathrm{O}_{2}$ equivalent/l. The assay's detection range was $<3 \%$ and the $\mathrm{CV}$ of the Intra assay was held $<10 \%$ and linearity was up to $250 \mu \mathrm{Mol}$ of $\mathrm{H}_{2} \mathrm{O}_{2}$ equivalent / [22].

\section{Paraoxonase (PON1) activity (U/L)}

For the estimation of PON1 activity, the method defined by Anwar et al. [23] was used. Using the reference formula, the activity of the enzyme was measured and stated in Unit/min/l. Intra assay CV was $<10 \%$ and the paraoxon hydrolysis rate was constant for up to $6 \mathrm{~min}$. The minimum measurable activity was between 80 and $100 \mathrm{U} / \mathrm{min} / \mathrm{L}$ for this assay.

\section{Arylesterase activity (KU/L)}

By adopting the protocol as previously adopted by Anwar et al. [23], the activity of arylesterase was evaluated using the given equation in the reference procedure. The $\mathrm{CV}$ was $<7 \%$ and the initial hydrolysis rate was stable for up to $5 \mathrm{~min}$.

\section{Serum malondialdehyde level ( $\mathrm{pM} / \mathrm{dl})$}

The serum level of malondialdehyde (MDA) was calculated by the thiobarbituric reactive substance assay (TBARS) reported by Al-Assaff and Takruri [24], which is based on the pink pigment-producing MDA reaction with thiobarbituric acid (TBA). For this, $500 \mu \mathrm{l}$ of the serum was mixed with $2.5 \mathrm{ml}$ of $10 \%$ TBA solution, then the tube was put for $15 \mathrm{~min}$ in a boiling water bath. It was then cooled in cold water and centrifuged for $5 \mathrm{~min}$ at $3000 \mathrm{~g}$. In a test tube, $2 \mathrm{ml}$ of the supernatant was applied to $1 \mathrm{ml}$ of $0.67 \%$ TBA solution and put for another $15 \mathrm{~min}$ in a boiling water bath, and finally cooled in tap water. The absorbance was measured at $532 \mathrm{~nm}$ using Biolab 310, Biolab Scientific Ltd. Canada against distilled water as a blank $[24,25]$.

\section{Catalase activity assay (KU/min)}

Catalase enzyme activity was measured by mixing the $100 \mu \mathrm{l}$ of serum sample in $1000 \mu \mathrm{l}$ substrate $(649 \mathrm{mmol} /$ $\mathrm{ml} \mathrm{H}_{2} \mathrm{O}_{2}$ in $59 \mathrm{mmol} / \mathrm{l}$ phosphate buffer saline, $\left.\mathrm{pH} 7.4\right)$. In the control test tube, the substrate was replaced with $1 \mathrm{ml}$ distilled water and in the standard tube, the serum was replaced with $100 \mu \mathrm{l}$ of distilled water. After $3 \mathrm{~min}$ of incubation at $37^{\circ} \mathrm{C}$, the reaction was terminated with ammonium molybdate $(32.4 \mathrm{mM})$. The optical density of the yellow-colored complex produced from molybdate and $\mathrm{H}_{2} \mathrm{O}_{2}$ was calculated at $374 \mathrm{~nm}$ against the blank using Biolab 310, Biolab Scientific Ltd. Canada. The equation of firstorder reaction $(\mathrm{k})$ was used to measure catalase enzyme activity:

$$
k U=\frac{2.303}{t} \times\left[\log \frac{S^{\circ}}{S-M}\right] \times \frac{\mathrm{Vt}}{\mathrm{Vs}}
$$

$S^{\circ}$ : optical density of standard; S: optical density of test sample; M: optical density of control sample; $\mathrm{V}_{\mathrm{t}}$ : overall volume of all components in the test tube; $\mathrm{V}_{\mathrm{s}}$ : total volume of serum sample [26].

\section{Histopathology of pancreas}

Pancreas tissues were taken out from the $10 \%$ formalin and embedded in paraffin to make the blocks. Sections of 4 to $5 \mu$ were sliced with Microtome [Bk-Mt $268 \mathrm{~m}$; Biobase Biodustry (Shandong) Co., Ltd.] for histopathological examination. The tissue sections were placed on a glass slide coated with albumin. It was then deparaffinized, rehydrated, and finally stained with hematoxylin and eosin stain. The stained slides were then examined under a light microscope after DPX mounting and covered with a coverslip [27].

\section{Statistical analysis}

The SPSS software version 23 was used for statistical analysis. All datasets were statistically demonstrated as mean \pm standard error. One-way Analysis of Variance (ANOVA) was used to find the significance of difference among various groups followed by turkey's post hoc test. The level of significance was actively considered at $p<0.05$ with 8 number of samples in each group $(n=8)$.

\section{Results}

\section{Antioxidant activity}

Effect of Euphorbia helioscopia on oxidative stress

The mean serum TAC level was increased significantly $(P \leq 0.05)$ in the EH2 group $\left(2.5 \pm 0.47^{\mathrm{b}} \mathrm{mM} / \mathrm{l}\right)$ as compared with other experiment groups (Table 1). There 
Table 1 Effect of Euphorbia helioscopia on oxidative stress markers

\begin{tabular}{llllllll}
\hline Groups & $\begin{array}{l}\text { PON1 (U/L) } \\
\boldsymbol{p}=\mathbf{0 . 0 0 5}\end{array}$ & $\begin{array}{l}\text { ARY (KU/L) } \\
\boldsymbol{p}=\mathbf{0 . 0 0 6}\end{array}$ & $\begin{array}{l}\text { TAC (mM/L) } \\
\boldsymbol{p}=\mathbf{0 . 0 3 6}\end{array}$ & $\begin{array}{l}\text { TOS (uM/L) } \\
\boldsymbol{p}=\mathbf{0 . 0 0 1}\end{array}$ & $\begin{array}{l}\text { MDA (pM/dl) } \\
\boldsymbol{p}=\mathbf{0 . 0 2}\end{array}$ & $\begin{array}{l}\text { Catalase (KU/min) } \\
\boldsymbol{p}=\mathbf{0 . 0}\end{array}$ & $\begin{array}{l}\text { SOD (ng/ml) } \\
\boldsymbol{p}=\mathbf{0 . 0 4 1}\end{array}$ \\
\hline NC & $18.60 \pm 3.62^{\mathrm{a}}$ & $140.88 \pm 5.5^{\mathrm{ab}}$ & $1.17 \pm 0.2^{\mathrm{ab}}$ & $22.56 \pm 4.72^{\mathrm{ab}}$ & $1.66 \pm 0.34^{\mathrm{ab}}$ & $16.93 \pm 2.06^{\mathrm{ab}}$ & $7.83 \pm 0.16^{\mathrm{ab}}$ \\
PC & $17.18 \pm 0.98^{\mathrm{a}}$ & $125.71 \pm 1.78^{\mathrm{a}}$ & $1.04 \pm 0.41^{\mathrm{a}}$ & $31.13 \pm 3.34^{\mathrm{b}}$ & $2.64 \pm 0.47^{\mathrm{bc}}$ & $10.07 \pm 0.71^{\mathrm{a}}$ & $5.17 \pm 0.8^{\mathrm{a}}$ \\
SC & $24.59 \pm 0.53^{\mathrm{ab}}$ & $147.18 \pm 6.83^{\mathrm{ab}}$ & $1.4 \pm 0.17^{\mathrm{ab}}$ & $23.26 \pm 1.97^{\mathrm{ab}}$ & $1.06 \pm 0.21^{\mathrm{ab}}$ & $17.56 \pm 0.68^{\mathrm{b}}$ & $6.52 \pm 0.89^{\mathrm{ab}}$ \\
EH1 & $26.24 \pm 2.57^{\mathrm{ab}}$ & $145.29 \pm 6.31^{\mathrm{ab}}$ & $1.61 \pm 0.2^{\mathrm{ab}}$ & $18.94 \pm 0.82^{\mathrm{a}}$ & $1.17 \pm 0.28^{\mathrm{bc}}$ & $19.37 \pm 4.29^{\mathrm{b}}$ & $7.87 \pm 0.15^{\mathrm{ab}}$ \\
EH 2 & $31.28 \pm 3.58^{\mathrm{b}}$ & $163.41 \pm 7.77^{\mathrm{b}}$ & $2.5 \pm 0.47^{\mathrm{b}}$ & $12.97 \pm 0.61^{\mathrm{a}}$ & $0.82 \pm 0.5^{\mathrm{a}}$ & $31.18 \pm 1.78^{\mathrm{c}}$ & $8.39 \pm 1.06^{\mathrm{b}}$ \\
\hline
\end{tabular}

Data are expressed as means \pm standard errors of a total of 8 samples for each group. Values with different letters in a column are significantly different $(P \leq 0.05)$. NC, negative control group; PC, positive control group (Diabetic rats without any treatment); SC (Standard control group (Diabetic rats treated with metformin at 1 mg/ $\mathrm{kg}$ body weight via oral lavage); EH1, Treatment group-I (Diabetic rats given methanolic extract of Euphorbia helioscopia at dose of $200 \mathrm{mg} / \mathrm{Kg}$ BW via oral lavage); EH2, Treatment group-II (Diabetic rats given methanolic extract of Euphorbia helioscopia at dose of $400 \mathrm{mg} / \mathrm{Kg}$ BW via oral lavage); PON1, Paraoxonase activity; ARY, Arylesterase activity, TAC; Total antioxidant capacity, TOS; Total oxidant status, SOD; Superoxide dismutase

was also a non-significant increase in TAC value in EH1 $\left(1.61 \pm 0.2^{\mathrm{ab}} \mathrm{mM} / \mathrm{l}\right)$ and SC group $\left(1.4 \pm 0.17^{\mathrm{ab}} \mathrm{mM} / \mathrm{l}\right)$ compared with the PC group $\left(1.04 \pm 0.41^{\mathrm{a}} \mathrm{mM} / \mathrm{l}\right)$. The difference between EH1 and EH2 was non-significant. Euphorbia helioscopia extract significantly $(P \leq 0.05)$ decreased the TOS in the EH1 $\left(18.94 \pm 0.82^{\mathrm{a}} \mathrm{uM} / \mathrm{l}\right)$ and EH2 groups $\left(12.97 \pm 0.61^{\mathrm{a}} \mathrm{uM} / \mathrm{l}\right)$ (Table 1$)$ as compared with the PC $\left(31.13 \pm 3.34^{\mathrm{b}} \mathrm{uM} / \mathrm{l}\right)$ group but the difference between the mean TOS value of EH1 and $\mathrm{EH} 2$ was not significant. The mean TOS value in the SC group was also decreased as compared with the $\mathrm{PC}$ group but the change was not significant. Euphorbia helioscopia methanolic extract significantly $(P \leq 0.05)$ increased the antioxidant enzyme SOD concentration in serum at the higher dose of $400 \mathrm{mg} / \mathrm{kg}$ in the EH2 group $\left(8.39 \pm 1.06^{\mathrm{b}}\right.$ $\mathrm{ng} / \mathrm{ml})$ as compared to the $\mathrm{PC}$ group $\left(5.17 \pm 0.8^{\mathrm{a}} \mathrm{ng} / \mathrm{ml}\right)$ but the increase in the Mean SOD value in SC and EH1 group was not significant as compared with the $\mathrm{PC}$ group (Table 1). A dose-dependent increase in serum catalase activity in the EH1 $\left(19.37 \pm 4.29^{\mathrm{b}} \mathrm{KU} / \mathrm{min}\right)$ and $\mathrm{EH} 2$ groups $\left(31.18 \pm 1.78^{\mathrm{c}} \mathrm{KU} / \mathrm{min}\right)$ as compared to the PC group $\left(10.07 \pm 0.71^{\mathrm{a}} \mathrm{KU} / \mathrm{min}\right)$ was observed. There was also a significant increase in the catalase activity of serum catalase activity of the SC group $\left(17.56 \pm 0.68^{\mathrm{b}} \mathrm{KU} / \mathrm{min}\right)$ as compared with the PC group $\left(10.07 \pm 0.71^{\mathrm{a}} \mathrm{KU} / \mathrm{min}\right)$. Statistically significant $(P \leq 0.05)$ decrease was observed in MDA levels in the EH2 group $\left(0.82 \pm 0.5^{\mathrm{a}} \mathrm{pM} / \mathrm{dl}\right)$ group as compared to the PC group $\left(2.64 \pm 0.47^{\mathrm{bc}} \mathrm{pM} / \mathrm{dl}\right)$. The lower dose of the plant non significantly decreased the serum MDA levels in the EH1 group $\left(1.17 \pm 0.28^{\text {bc }}\right.$ $\mathrm{pM} / \mathrm{dl})$ and SC group $\left(1.06 \pm 0.21^{\mathrm{ab}} \mathrm{pM} / \mathrm{l}\right)$ as compared to the PC group $\left(2.64 \pm 0.47^{\mathrm{bc}} \mathrm{pM} / \mathrm{dl}\right)$. There was a significantly $(P \leq 0.05)$ increase in the serum arylesterase and paraoxonase activities in the EH2 group $\left(163.41 \pm 7.77^{\mathrm{b}}\right.$ $\mathrm{KU} / \mathrm{l}$ and $31.28 \pm 3.58^{\mathrm{b}} \mathrm{U} / \mathrm{l}$ respectively) as compared to the PC group $\left(125.71 \pm 1.78^{\mathrm{a}} \mathrm{KU} / \mathrm{l}\right.$ and $17.18 \pm 0.98^{\mathrm{a}}$ $\mathrm{U} / \mathrm{l}$ respectively). Activities of these enzymes were also increased in the EH1, and SC groups, but the change was non-significant as compared with the PC group (Table 1).

\section{Antidiabetic activity \\ Effect of Euphorbia helioscopia on insulin, glucagon, glucose, and C-peptide}

The serum level of insulin was decreased significantly $(P \leq 0.05)$ in the EH1 $\left(13.08 \pm 0.95^{\mathrm{a}} \mathrm{ng} / \mathrm{ml}\right)$ group as compared to the PC $\left(22.42 \pm 3.03^{\mathrm{b}} \mathrm{ng} / \mathrm{ml}\right)$ group. Decrease in serum insulin level was also observed in EH2 $\quad\left(15.16 \pm 1.27^{\mathrm{ab}} \mathrm{ng} / \mathrm{ml}\right), \quad \mathrm{SC} \quad\left(17.23 \pm 1.65^{\mathrm{ab}} \mathrm{ng} /\right.$ $\mathrm{ml})$, and NC groups $\left(17.26 \pm 1.84^{\mathrm{ab}} \mathrm{ng} / \mathrm{ml}\right)$ as compared to the PC $\left(22.42 \pm 3.03^{\mathrm{b}} \mathrm{ng} / \mathrm{ml}\right)$ group (Fig. 1: A) but the change was statistically non-significant. The mean serum levels of glucagon, glucose and C-peptide were significantly $(P \leq 0.05)$ increased in $\mathrm{PC}$ group $\left(3135.78 \pm 189.46^{\mathrm{b}} \quad \mathrm{pg} / \mathrm{ml}, \quad 191.24 \pm 17.75^{\mathrm{b}} \mathrm{mg} / \mathrm{dl}\right.$, $671.70 \pm 109.75^{\mathrm{b}} \mathrm{pg} / \mathrm{ml}$ respectively) as compared to NC group $\left(1928.58 \pm 339.85^{\mathrm{a}} \mathrm{pg} / \mathrm{ml}, 137.20 \pm 16.49^{\mathrm{a}} \mathrm{mg} / \mathrm{dl}\right.$, $372.85 \pm 20.46^{\mathrm{a}} \mathrm{pg} / \mathrm{ml}$ respectively) (Fig. 1: B, C, D). All these parameters were decreased significantly $(P \leq 0.05)$ in the EH1, EH2, and SC groups as compared to the PC group (Fig. 1: A, B, C, D).

\section{Effect of Euphorbia helioscopia on carbohydrate metabolic enzymes}

Pyruvate Kinase, Glucose 6 phosphate dehydrogenase, phosphofructokinase, and glucokinase levels in serum were increased in the $\mathrm{EH} 2$ group $\left(35.91 \pm 6.19^{\mathrm{b}} \mathrm{ng} / \mathrm{ml}\right.$, $8.12 \pm 1.39^{\mathrm{b}} \mathrm{ng} / \mathrm{ml}, 70.44 \pm 4.4^{\mathrm{b}} \mathrm{ng} / \mathrm{ml}, 9.1 \pm 0.71^{\mathrm{b}} \mathrm{ng} / \mathrm{ml}$ respectively) as compared to the PC group $\left(13.69 \pm 2.48^{\mathrm{a}}\right.$ $\mathrm{ng} / \mathrm{ml}, 1.57 \pm 1.43^{\mathrm{a}} \mathrm{ng} / \mathrm{ml}, 23.29 \pm 10.23^{\mathrm{a}} \mathrm{ng} / \mathrm{ml}, 2.52 \pm 1^{\mathrm{a}}$ $\mathrm{ng} / \mathrm{ml}$ respectively; Fig. 2: A, B, C, D). However, a significant difference was not seen in the serum levels of these enzymes in the EH1 group as compared to NC and SC groups. 


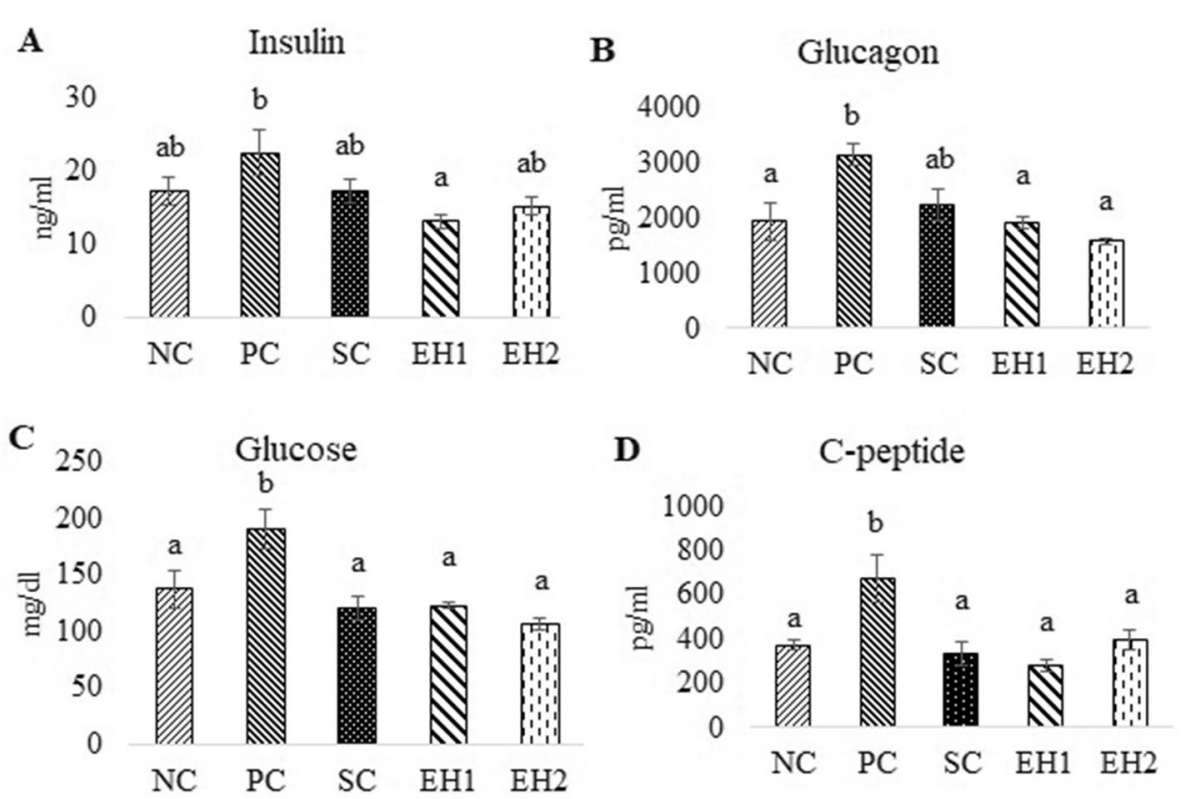

Fig. 1 Effect of Euphorbia helioscopia on insulin, glucagon, glucose and C-peptide. Data are expressed as means \pm standard errors of a total of 8 samples for each group. Bars with different letters are significantly different $(P \leq 0.05)$. NC, negative control group; $P C$, positive control group (Diabetic rats without any treatment); SC (Standard control group (Diabetic rats treated with metformin at $1 \mathrm{mg} / \mathrm{kg}$ body weight via oral lavage); EH1, Treatment group-I (Diabetic rats given methanolic extract of Euphorbia helioscopia at dose of $200 \mathrm{mg} / \mathrm{Kg}$ BW via oral lavage); EH2, Treatment group-II (Diabetic rats given methanolic extract of Euphorbia helioscopia at dose of $400 \mathrm{mg} / \mathrm{Kg}$ BW via oral lavage)

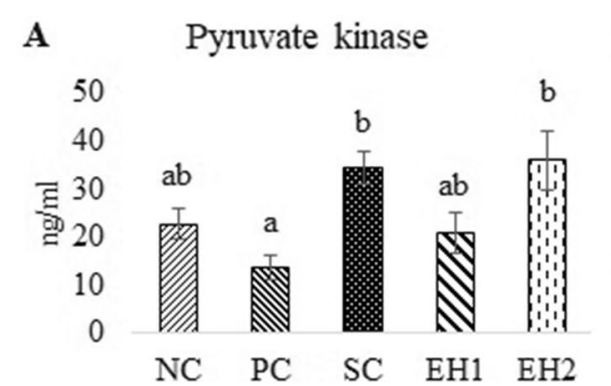

C Phosphofructokinase

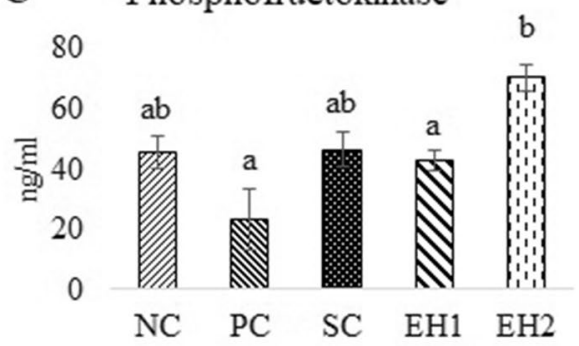

\section{B Glucose 6 Phosphate}

dehydrogenase

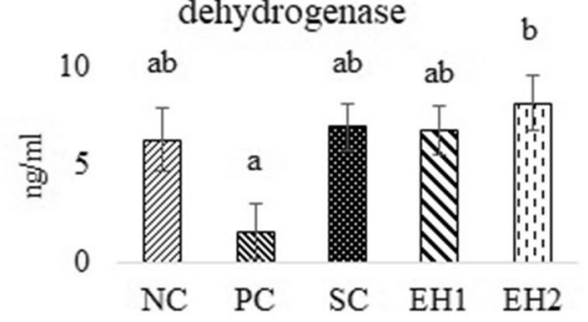

D

Glucokinase

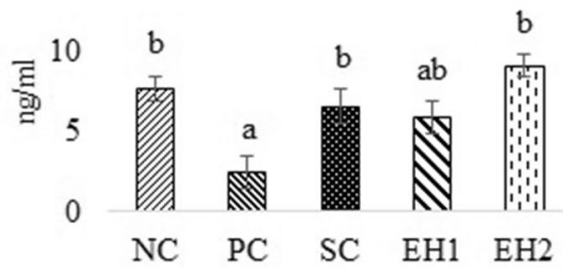

Fig. 2 Effect of Euphorbia helioscopia on carbohydrate enzymes. Data are expressed as means \pm standard errors of a total of 8 samples for each group. Bars with different lowercase letters are significantly different $(P \leq 0.05)$. NC, negative control group; PC, positive control group (Diabetic rats without any treatment); SC (Standard control group (Diabetic rats treated with metformin at $1 \mathrm{mg} / \mathrm{kg}$ body weight via oral lavage); EH1, Treatment group-I (Diabetic rats given methanolic extract of Euphorbia helioscopia at dose of $200 \mathrm{mg} / \mathrm{Kg}$ BW via oral lavage); EH2, Treatment group-II (Diabetic rats given methanolic extract of Euphorbia helioscopia at dose of $400 \mathrm{mg} / \mathrm{Kg}$ BW via oral lavage 


\section{Effect of Euphorbia helioscopia on amylin and leptin}

Serum levels of amylin and leptin were significantly $(P \leq 0.05)$ decreased in the EH2 $\left(2317.53 \pm 63.15^{\mathrm{b}}\right.$ $\mathrm{ng} / \mathrm{ml}$ and $0.67 \pm 0.06^{\mathrm{a}} \mathrm{ng} / \mathrm{ml}$ respectively), and SC $\left(2075.1 \pm 40.67^{\mathrm{ab}} \mathrm{ng} / \mathrm{ml}\right.$ and $1.425 \pm 0.19^{\mathrm{ab}} \mathrm{ng} /$ $\mathrm{ml}$ respectively) groups in comparison to PC group $\left(2962.45 \pm 213.81^{\mathrm{a}} \mathrm{ng} / \mathrm{ml}\right.$ and $1.81 \pm .39^{\mathrm{b}} \mathrm{ng} / \mathrm{ml}$ respectively) but there was a non-significant decrease in the serum leptin levels in EH1 group when compared to the PC group. However, the decrease in serum amylin level of EH1 was significant as compared to the PC group (Table 2). The difference of both amylin and leptin in EH1 was non-significant from the $\mathrm{EH} 2$ group.

\section{Effect of Euphorbia helioscopia on thyroid hormones}

Mean values of T3 and T4 were significantly $(P \leq 0.05)$ increased in the EH2 group $\left(77.35 \pm 4.59^{\mathrm{b}} \mathrm{pg} / \mathrm{ml}\right.$ and $73.67 \pm 14.11^{\mathrm{b}} \mathrm{ng} / \mathrm{ml}$ respectively) as compared to the PC group $\left(40.66 \pm 6.42^{\mathrm{a}} \mathrm{pg} / \mathrm{ml}\right.$ and $18.94 \pm 3.08^{\mathrm{a}} \mathrm{ng} / \mathrm{ml}$ respectively). Statistically, a non-significant increase in T3 and T4 levels was also observed in the EH1 group compared to the PC group. Serum TSH level was also increased in the EH1 and EH2 groups as compared to the PC group in a dose-dependent manner. However, this increase in TSH was statistically non-significant. Supplementation of metformin also increased significantly $(P \leq 0.05)$ the serum TSH in the SC group as compared to the PC group (Table 2).

\section{Effect of Euphorbia helioscopia on lipid profile}

Total cholesterol, LDL and triglyceride levels were significantly $(P \leq 0.05)$ decreased in EH2 group $\left(143.27 \pm 1.39^{\mathrm{a}}\right.$ $\mathrm{mg} / \mathrm{dl}, \quad 172.21 \pm 12.41^{\mathrm{a}} \mathrm{mg} / \mathrm{dl}, \quad 12.46 \pm 12.50^{\mathrm{a}} \mathrm{mg} / \mathrm{dl}$ respectively) as compared to $\mathrm{PC}$ group $\left(271.04 \pm 27.39^{\mathrm{b}}\right.$ $\mathrm{mg} / \mathrm{dl}, 288.17 \pm 40.06^{\mathrm{b}} \mathrm{mg} / \mathrm{dl}, 152.70 \pm 49.86^{\mathrm{b}}$ respectively) (Fig. 3: A, B, D). Whereas serum HDL levels were significantly increased in the EH1 $\left(120.44 \pm 2.41^{\mathrm{b}} \mathrm{mg} /\right.$ dl) and $\mathrm{EH} 2$ groups $\left(131.10 \pm 2.79^{\mathrm{b}} \mathrm{mg} / \mathrm{dl}\right)$ as compared to the PC group $\left(81.27 \pm 9.78^{\mathrm{a}} \mathrm{mg} / \mathrm{dl}\right)$ and no significant change was observed among $\mathrm{NC}, \mathrm{EH} 1$, and $\mathrm{EH} 2$ groups (Fig. 3: C). There was no significant difference in all the lipid profile parameters of the SC group as compared to the $\mathrm{PC}$ group.

\section{Effect of Euphorbia helioscopia on pancreas histopathology}

Tissue samples from the pancreas were collected from Wistar rats of each experimental group to analyze histopathological changes in pancreatic tissue. Photomicrographs showing histological changes in rat pancreas of all groups are presented in Fig. 4. As shown in Fig. 4. NC, the pancreas of rats in the negative control group had fully active islets of Langerhans with normal pancreatic beta cells marked with blue-colored arrows. However, in the PC group (diabetic rats), the pancreas showed destruction of $\beta$-cells, small-sized islets of Langerhans, and loss of cellular contents as shown in Fig. 4. PC. In the diabetic rats treated with MthEh at both doses, as shown in Fig. 4. EH1 and Fig. 4. EH2, there was a dose-dependent restoration of the normal histological structure showing normal pancreatic parenchyma with fully active $\beta$-cells in islets of Langerhans.

\section{Discussion}

The present study was conducted to examine the potential of Euphorbia helioscopia (a medicinal plant) as an antioxidant and antidiabetic agent in a type 2 diabetic rat model. The impact of the Euphorbia helioscopia treatment on carbohydrate metabolism and thyroid gland was also evaluated. The antidiabetic and antioxidant effects of Euphorbiaceae family have been described previously in different animal models [28]. The rise in insulin and $\mathrm{C}$-peptide levels in the untreated diabetic rats of the PC group is in contrast to type 2 diabetic animals, where elevated blood glucose is followed by increased insulin synthesis and insulin resistance resulting in hyperglycemia [29]. In humans with type 2 diabetes, the glucose

Table 2 Effect of Euphorbia helioscopia on Amylin, Leptin and Thyroid hormones

\begin{tabular}{llllll}
\hline Groups & $\begin{array}{l}\text { Amylin }(\mathbf{p g} / \mathbf{m l}) \\
\boldsymbol{p}=\mathbf{0 . 0 0 7}\end{array}$ & $\begin{array}{l}\text { Leptin }(\mathbf{n g} / \mathbf{m l}) \\
\boldsymbol{p}=\mathbf{0 . 0 3 9}\end{array}$ & $\begin{array}{l}\text { T3 }(\mathbf{p g} / \mathbf{m l}) \\
\boldsymbol{p}=\mathbf{0 . 0 1 9}\end{array}$ & $\begin{array}{l}\text { T4 (ng/ml) } \\
\boldsymbol{p}=\mathbf{0 . 0 1 8}\end{array}$ & $\begin{array}{l}\text { TSH }(\mathbf{n g} / \mathbf{m l}) \\
\boldsymbol{P}=\mathbf{0 . 0 3}\end{array}$ \\
\hline NC & $1736.35 \pm 75.97^{\mathrm{a}}$ & $1.06 \pm 0.32^{\mathrm{ab}}$ & $48.44 \pm 0.47^{\mathrm{ab}}$ & $59.97 \pm 13.13^{\mathrm{ab}}$ & $84.90 \pm 21.38^{\mathrm{ab}}$ \\
PC & $2962.45 \pm 213.81^{\mathrm{c}}$ & $1.81 \pm .39^{\mathrm{b}}$ & $40.66 \pm 6.42^{\mathrm{a}}$ & $18.94 \pm 3.08^{\mathrm{a}}$ & $51.42 \pm 28.63^{\mathrm{a}}$ \\
SC & $2075.1 \pm 40.67^{\mathrm{ab}}$ & $1.425 \pm 0.19^{\mathrm{ab}}$ & $54.97 \pm 10.19^{\mathrm{ab}}$ & $74.55 \pm 14.94^{\mathrm{b}}$ & $125.24 \pm 11.71^{\mathrm{b}}$ \\
EH1 & $2078.19 \pm 55.38^{\mathrm{ab}}$ & $1.12 \pm 0.05^{\mathrm{ab}}$ & $70.35 \pm 5.52^{\mathrm{ab}}$ & $67.27 \pm 9.38^{\mathrm{ab}}$ & $117.03 \pm 4.17^{\mathrm{ab}}$ \\
EH2 & $2317.53 \pm 63.15^{\mathrm{b}}$ & $0.67 \pm 0.06^{\mathrm{a}}$ & $77.35 \pm 4.59^{\mathrm{b}}$ & $73.67 \pm 14.11^{\mathrm{b}}$ & $123.09 \pm 8.97^{\mathrm{ab}}$ \\
\hline
\end{tabular}

Data are expressed as means \pm standard errors of a total of 8 samples for each group. Values having different lowercase letters in a column are significantly different $(P \leq 0.05)$. NC, negative control group; $P C$, positive control group (Diabetic rats without any treatment); SC (Standard control group (Diabetic rats treated with metformin at $1 \mathrm{mg} / \mathrm{kg}$ body weight via oral lavage); EH1, Treatment group-I (Diabetic rats given methanolic extract of Euphorbia helioscopia at dose of $200 \mathrm{mg} / \mathrm{Kg}$ BW via oral lavage); EH2, Treatment group-II (Diabetic rats given methanolic extract of Euphorbia helioscopia at dose of $400 \mathrm{mg} / \mathrm{Kg} \mathrm{BW}$ via oral lavage; T3, triiodothyronine; T4, thyroxin, $\mathrm{TSH}$; thyroid stimulating hormone 


\section{A}

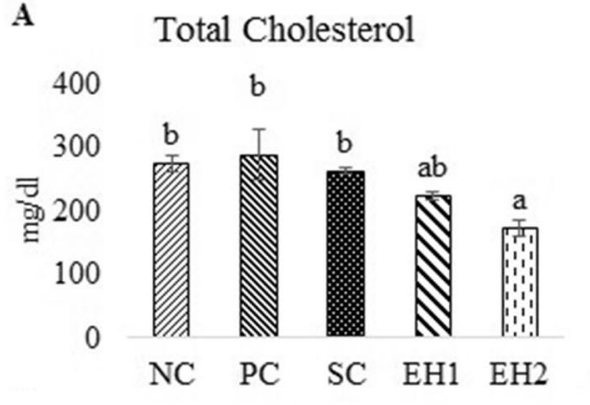

C

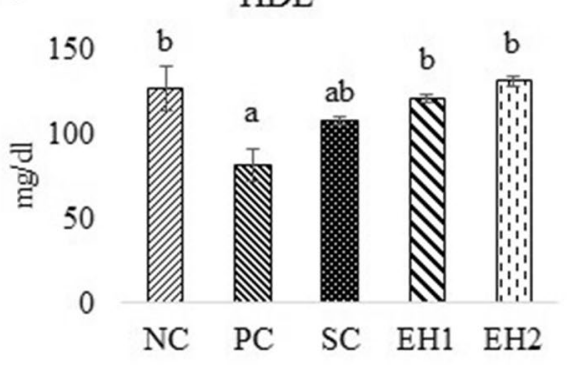

B

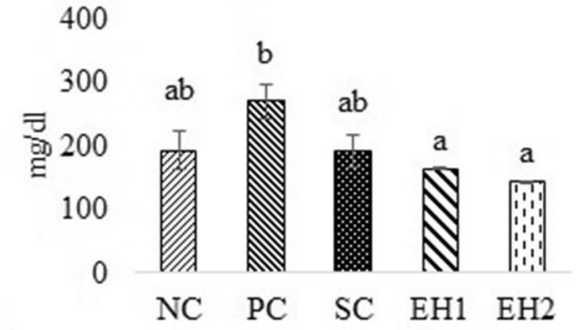

D

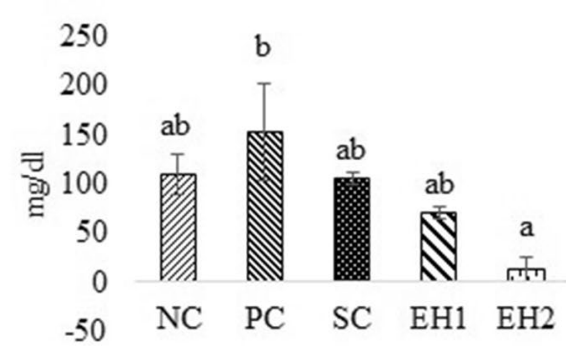

Fig. 3 Effect of Euphorbia helioscopia on lipid profile. Data are expressed as means \pm standard errors of a total of 8 samples for each group. Bars with different letters are significantly different $(\boldsymbol{P} \leq 0.05)$. NC, negative control group; PC, positive control group (Diabetic rats without any treatment); SC (Standard control group (Diabetic rats treated with metformin at $1 \mathrm{mg} / \mathrm{kg}$ body weight via oral lavage); EH1, Treatment group-I (Diabetic rats given methanolic extract of Euphorbia helioscopia at dose of $200 \mathrm{mg} / \mathrm{Kg}$ BW via oral lavage); EH2, Treatment group-II (Diabetic rats given methanolic extract of Euphorbia helioscopia at dose of $400 \mathrm{mg} / \mathrm{Kg}$ BW via oral lavage); HDL, high density lipoprotein; LDL, low density lipoprotein

challenge causes a substantially higher increase in blood glucose than in healthy individuals and is similar to that found in rats with diabetes caused by STZ-NA. Hyperglycemia observed after glucose load in type 2 diabetic humans normally results from both insulin resistance and impaired $\beta$-cell function [30-32], which is similar to our study where the insulin level is also increased along with glucagon and glucose in the PC group. But the treatment with methanolic extract of the plant significantly revered the levels of insulin, glucose, glucagon, and C-peptide in EH1 and EH2 groups compared with the metformin-treated group SC, which shows that the plant extract has reversed the $\beta$-cell function. This antidiabetic activity of the plant extract might be due to the antioxidant potential of this plant extract positively correlated with its antidiabetic potential in a previous in vitro study. This study explains that the methanolic extract of the plant is rich in chlorogenic acid, ferulic acid, caffeic acid, catechin, rutin, and quercetin. These phenolics and flavonoids are positively correlated with antioxidant and antidiabetic activity [15]. Previously it was observed that the antioxidant activity of the plant might be due to the presence of phenolic contents in its methanolic extract which are reported to play a vital role in scavenging the free radicals, preventing the oxidation process, and protecting cells from injury to avoid the danger of degenerative diseases including type II diabetes [15, 33-35]. The total antioxidant capacity was increased whereas the total oxidant status was decreased significantly in the current study. Moreover, the SOD, catalase, arylesterase, and paraoxonase activities were significantly increased whereas malondialdehyde levels were significantly decreased. Previous studies show that the methanolic extract of the plant shows antioxidant activity due to the presence of its phenolic contents $[15,21]$.

Due to the insufficiency of insulin, there is increased hepatic glucose output, failing to activate the enzymes for glycolysis and glycogenesis ultimately increasing blood glucose level [35]. Activities of glucokinase and glucose 6-phosphate dehydrogenase, phosphofructokinase, and pyruvate kinase were decreased remarkably in the positive control group in the current study. Euphorbia helioscopia and metformin-induced significant increase in serum glucose-6-phosphate dehydrogenase activity which might enhance the entry of glucose into the pentoses monophosphate shunt and this may cause an increase in producing the reducing agent, NADPH, with an associated reduction in oxidative stress [36]. The decline in pyruvate kinase activity observed in the current experiment suggests the decreased glucose 

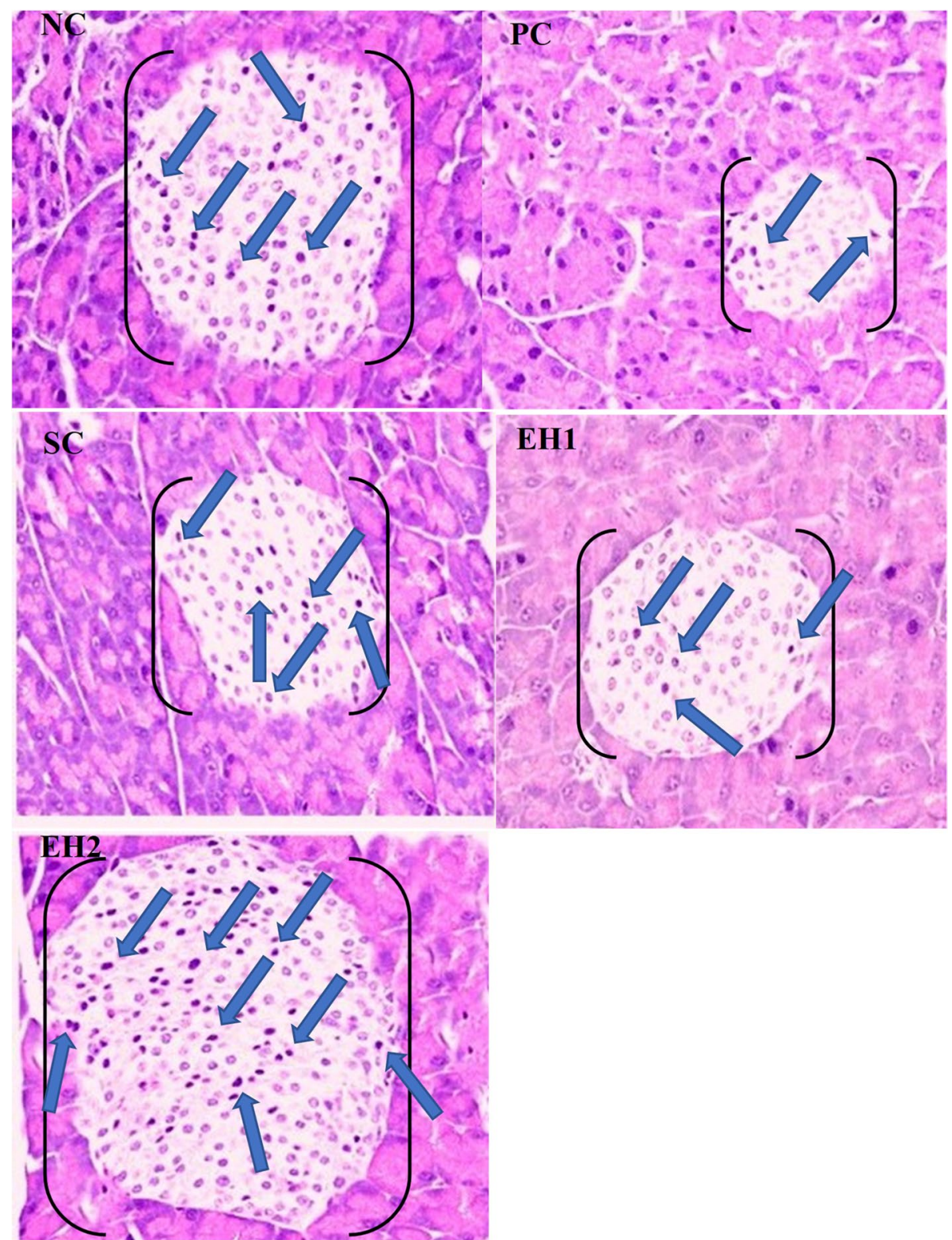

Fig. 4 Effect of Euphorbia helioscopia on pancreas histopathology ( $H$ and E staining); 40X; NC: Photograph showing tissue of rat pancreas of negative control group; PC: Photograph showing tissue of rat pancreas of positive control group; SC: Photograph showing tissue of rat pancreas of standard control group; EH1: Photograph showing tissue of rat pancreas of methanolic extract of Euphorbia helioscopia at dose $200 \mathrm{mg}$ kg; EH2: Photograph showing tissue of rat pancreas of methanolic extract of Euphorbia helioscopia at dose $400 \mathrm{mg} \mathrm{kg}$. Brackets [ represent the size of islet of Langerhans and the blue colored arrows show the pancreatic beta cells

utilization (glycolysis) and enhanced synthesis of glucose (gluconeogenesis) demonstrating that these pathways were changed [37]. Euphorbia helioscopia and metformin also enhanced the glucokinase and pyruvate kinase activity thereby inducing the active utilization of glucose. Carbohydrate metabolism and pancreatic hormones are effectively regulated by thyroid hormones [38]. In the current study, level of T3, T4 and TSH were decreased in the untreated diabetic group. The decrease in T3 may also be explained by impaired T4 conversion into $\mathrm{T} 3$ which is involved in the improvement of glycemic control [39]. Serum T3, T4 and TSH levels were restored after Euphorbia helioscopia treatment in current study. These findings are supported by the previous observations where a significant decrease in the level of serum thyroid hormone was observed in 
experimentally induced hyperglycemic rats [40]. The phenolic contents present in the methanolic extract are ultimately responsible for the correction of thyroid hormones by ameliorating the oxidative stress that leads to diabetes and thyroid hormone imbalance. Thyroid dysfunction results as a complication of diabetes, hence treating diabetes can restore the serum levels of thyroid hormones [41]. Leptin is a vital hormone derived from adipose tissue that has been observed to play a significant role in various pathways prompting the risk of diabetes [42]. A significant decrease in serum leptin levels observed after Euphorbia helioscopia treatment can be correlated with increased insulin sensitivity in the treated groups as previous studies also suggested an inverse relationship between insulin levels and leptin levels [43-45]. Amylin is a peptide hormone that is co-localized and co-secreted with insulin from $\beta$ cells of the pancreas $[21,46,47]$. In the present study, a significant decrease in amylin levels was observed after $E$. helioscopia treatment. Total cholesterol, triglycerides, and LDL levels were reduced significantly whereas HDL levels were increased after E. helioscopia treatment. Previously it has been reported that methanolic extract of E. helioscopia lowered the total cholesterol, LDL, triglycerides and increased the HDL in the liver and serum of the paracetamol-induced oxidative stress of a mouse model [48]. Euphorbia hirta leaf extract treatment in diabetic rats decreased the elevated levels of TC, TG, LDL, and VLDL while HDL levels were increased to the normal values [49]. A possible mechanism in normalizing the lipid profile of diabetic rats treated with the plant extract may be the antioxidant activity of the plant's phenolic contents that delay the lipid peroxidation process through their free radical scavenging activity [50]. In our previous report in which the methanolic extract was quantitatively analyzed for different phenolic contents including gallic acid, hydroxybenzoic acid, chlorogenic acid, caffeic acid, and vanillic acid, and flavonoid contents including catechin acid, quercetin and rutin showed maximum antioxidant ability by scavenging DPPH and ABTS radicals [15].

Histopathological investigation of the pancreas indicated that diabetic rats treated with methanolic extract of the plant in EH1 and EH2 groups resulted in substantially normalizing the histoarchitecture of the endocrine portion of the pancreas particularly the $\beta$-cells in islets of Langerhans in a dose-dependent manner. An increase in the number of insulin-producing $\beta$-cells in pancreatic islets of Langerhans confirmed that a phenomenon of regeneration was activated in plant extracts treated groups. Diabetic rats of the PC group showed a significant reduction in the size of islets of Langerhans, pancreatic $\beta$-cells destruction, loss of cellular contents, nuclear shrinkage, and pyknosis, indicating the necrotic changes. These degenerative effects exerted by streptozotocin on pancreatic $\beta$-cells could be explained by its potential to generate reactive oxygen species (ROS) inside the $\beta$-cells and over-production of insulin from the pancreatic beta cells to compensate for insulin insufficiency due to insulin resistance [51]. The generation of these ROS leads to simultaneous lipid peroxidation and a massive rise in the concentration of cytosolic calcium resulting in rapid destruction of insulin-secreting pancreatic $\beta$-cells [52]. Moreover, streptozotocin also enhanced the $\beta$-cells damage by decreasing the activities of antioxidant enzymes inside the pancreas [52]. Treatment with the plant extract enhanced the viability, proliferation, and regeneration of destructed $\beta$-cells possibly by their protective and antioxidant potential leading to the subsequent increase in insulin production and secretion. These results are supported by the previous research studies [53]. This improvement in the beta cells by E. helioscopia methanolic extracts treatments in the same line with many studies which have reported that quercetin in the methanolic extract of E. helioscopia can inhibit pancreatic damage, supporting the regeneration of the pancreatic islets and enhancing its power to keep normal blood glucose levels in diabetesinduced rats [53, 54].

The main focus of the current research was to evaluate the effect of methanolic extract of E. helioscopia on the carbohydrate metabolic enzymes, oxidative stress, and antidiabetic activity. However, the study was limited to the evaluation of these parameters in the serum of the diabetic model of male rats evaluating the effect of the plant extract on the pancreas tissues. Moreover, the components of the plant extract were not separated, to examine the effect of plant extract as a whole in the initial stage of the research. The female rats were not included in the study due to the protective effect of female hormones, such as estrogen, against metabolic abnormalities [55]. As a future perspective, the current study will be extended to evaluate the toxic and therapeutic effects of each bioactive component of the plant extract on the antidiabetic activity, oxidative stress, and carbohydrate metabolism at a molecular and genetic level.

\section{Conclusion}

In conclusion oral treatment with Euphorbia helioscopia methanolic extract was able to modulate the carbohydrate metabolic enzymes Pyruvate Kinase, Glucose 6 phosphate dehydrogenase, phosphofructokinase, and glucokinase in serum and can mitigate the oxidative stress and improve the activity of the antioxidant enzymes ultimately reversing the pathogenesis of type 2 diabetes. According to the results of current study 
the selected plant is recommended for its antidiabetic use. However, its bioactive constituents having the antiinflammatory and antioxidant activity must be characterized and isolated for further investigation of its molecular mechanism involved at cellular level. So, as a future perspective they can be used as antidiabetic drug agent in human population.

\begin{abstract}
Abbreviations
TOS: Total Oxidant Status; MDA: Malondialdehyde; TBARS: Thiobarbituric reactive substance assay; TBA: Thiobarbituric acid; TAC:Total antioxidant capacity; NC: Negative control group; PC: Positive control group (Diabetic rats without any treatment); SC : Standard control group (Diabetic rats treated with metformin at $1 \mathrm{mg} / \mathrm{kg}$ body weight via oral lavage); EH1:Treatment group-I (Diabetic rats given methanolic extract of Euphorbia helioscopia at dose of $200 \mathrm{mg} / \mathrm{Kg}$ BW via oral gavage); EH2: Treatment group-II (Diabetic rats given methanolic extract of Euphorbia helioscopia at dose of $400 \mathrm{mg} / \mathrm{Kg}$ BW via oral gavage).
\end{abstract}

\section{Acknowledgements}

The authors acknowledge the department of Physiology, Government College University Faisalabad, Pakistan for extending their facilities for this research project in terms of providing funds, experimental animals station and labs.

\section{Authors' contributions}

IM and HA conceptualized the study, IM performed the antioxidant, carbohydrate metabolism and antidiabetic analysis. HA is major supervisor of IM PhD research project. IM and SI participated in the technical writing of the manuscript. HA and MUI conducted a critical review and editing of the manuscript. All authors read and approved the final manuscript.

\section{Funding}

Not applicable.

\section{Availability of data and materials}

The datasets used and/or analyzed during the current study are available from the corresponding author on reasonable request.

\section{Declarations}

\section{Ethics approval and consent to participate}

All experimental procedures in the current study, including the use of plants and rats, were approved by the Directorate of Advance studies, Government College University, Faisalabad, Pakistan, (GCUF/DAS/19/2470) and Animal Care and Ethical Committee, Government College University Faisalabad (GCUF/ERC/2223). All the procedures involving rats' model were carried out in accordance with the ARRIVE guidelines. All the experiments on plants were in accordance with guidelines of Government College University, Faisalabad, Pakistan.

\section{Consent for publication}

Not applicable.

\section{Competing interests}

All the authors declare that they have no conflict of interest.

\section{Author details}

'Department of Physiology, Faculty of Life Sciences, Government College University, Faisalabad, Pakistan. ${ }^{2}$ Department of Zoology, Wildlife and Fisheries, University of Agriculture, Faisalabad, Pakistan.

Received: 20 April 2021 Accepted: 6 January 2022

Published online: 25 January 2022

\section{References}

1. Júnior IIS, Barbosa HM, Carvalho DC, Barros RA, Albuquerque FP, Da Silva DHA, et al. Brazilian Morus nigra attenuated hyperglycemia, dyslipidemia, and prooxidant status in alloxan-induced diabetic rats. Sci World J. 2017;2017. https://doi.org/10.1155/2017/5275813.

2. Atlas D. International diabetes federation. IDF diabetes Atlas. 7th ed. Brussels: International Diabetes Federation; 2015.

3. Verry C, Sancey L, Dufort S, Le Duc G, Mendoza C, Lux F, et al. Treatment of multiple brain metastases using gadolinium nanoparticles and radiotherapy: NANO-RAD, a phase I study protocol. BMJ Open. 2019;9(2):e023591.

4. Basit A, Fawwad A, Siddiqui SA, Baqa K. Current management strategies to target the increasing incidence of diabetes within Pakistan. Diabetes Metab Syndr Obes. 2019;12:85.

5. Karunamoorthi K, Jegajeevanram K, Vijayalakshmi J, Mengistie E. Traditional medicinal plants: a source of phytotherapeutic modality in resource-constrained health care settings. Evid-Based Complement Altern Med. 2013;18(1):67-74.

6. Oliveira HC, dos Santos MP, Grigulo R, Lima LL, Martins DT, Lima JC, et al. Antidiabetic activity of Vatairea macrocarpa extract in rats. J Ethnopharmacol. 2008;115(3):515-9.

7. Maritim A, Sanders A, Watkins lii J. Diabetes, oxidative stress, and antioxidants: a review. Biochem. Mol Toxicol. 2003;17(1):24-38.

8. Park K-H, Koh D-S, Lee S-H, Jung I-M, Kim K-H, Lee C-H, et al. Antiallergic and anti-asthmatic activity of helioscopinin-a, a polyphenol compound, isolated from Euphorbia helioscopia. J Microbiol Biotechnol. 2001;11(1):138-42.

9. Barla A, Birman H, Kültür Ş, Öksüz S. Secondary metabolites from Euphorbia helioscopia and their vasodepressor activity. Turk J Chem. 2006;30(3):325-32.

10. Uzair M, Loothar B, Choudhary B. Biological screening of Euphorbia helioscopia L. Pak J Pharm Sci. 2009;22(2):184-6.

11. Mu S-Z, Shang S, Yan C, Yang F-M, Hao X-J. Study on chemical constituents of Euphorbia helioscopia and their antitumor activities. Zhong Yao Cai. 2013;36(7):1092-6.

12. Saleem U, Ahmad B, Ahmad M, Hussain K, Bukhari NI. Anti-nociceptive, anti-inflammatory and anti-pyretic activities of latex and leaves methanol extract of Euphorbia helioscopia. Asian Pac J Trop Dis. 2015;5(4):322-8.

13. Webster GL. Classification of the Euphorbiaceae. Ann Missouri Bot Gard. 1994;81:3-32.

14. Bajaj S, Khan A. Antioxidants and diabetes. Indian J Endocrinol Metab. 2012;16(Suppl 2):S267.

15. Mustafa I, Faisal MN, Hussain G, Muzaffar H, Imran M, ljaz MU, et al. Efficacy of Euphorbia helioscopia in context to a possible connection between antioxidant and antidiabetic activities: a comparative study of different extracts. BMC Compl Alternative Med. 2021;21(1):1-12.

16. Buyukdere Y, Gulec A, Akyol A. Cafeteria diet increased adiposity in comparison to high fat diet in young male rats. PeerJ. 2019;7:e6656.

17. Brahmanaidu P, Uddandrao VS, Sasikumar V, Naik RR, Pothani S, Begum MS, et al. Reversal of endothelial dysfunction in aorta of streptozotocinnicotinamide-induced type-2 diabetic rats by S-Allylcysteine. Mol Cell Biochem. 2017;432(1-2):25-32.

18. Kamboj A, Kumar S, Kumar V. Evaluation of antidiabetic activity of hydroalcoholic extract of cestrum nocturnum leaves in streptozotocininduced diabetic rats. Adv Pharmacol Pharm Sci. 2013;2013.

19. Devi S, Kumar M. In-vivo Antidiabetic activity of Methanolic extract of Euphorbia hirta L. Int J Diab Endocrinol. 2017;2(3):36.

20. Varadharajan Madhavan AM, Lalitha DS, Yoganarasimhan S. Studies on anti-hyperglycemic effect of Euphorbia antiquorum L. root in diabetic rats. J Intercult Ethnopharmacol. 2015:4(4):308.

21. Saleem U, Ahmad B, Ahmad M, Hussain K, Bukhari NI. Investigation of in vivo antioxidant activity of Euphorbia helioscopia latex and leaves methanol extract: a target against oxidative stress induced toxicity. Asian Pac J Trop Med. 2014;7:S369-75.

22. Nisar J, Mustafa I, Anwar H, Sohail MU, Hussain G, Ullah MI, et al. Shiitake culinary-medicinal mushroom, Lentinus edodes (Agaricomycetes): a species with antioxidant, immunomodulatory, and hepatoprotective activities in hypercholesterolemic rats. Int J Med Mushrooms. 2017;19(11):981-90.

23. Anwar H, Suchodolski JS, Ullah MI, Hussain G, Shabbir MZ, Mustafa I, et al. Shiitake culinary-medicinal mushroom, Lentinus edodes 
(Agaricomycetes), supplementation alters gut microbiome and corrects dyslipidemia in rats. Int J Med Mushrooms. 2019;21(1):79-88.

24. Al-Assaff AA, Takruri HR. Feeding Sprague dawley rats with Jordanian wild edible plants and a high fat diet reduced the malondialdehyde levels. J Agric Sci. 2019;11(10):71-9.

25. Sattar M, Anwar H, Faisal MN, Hussain G, Irfan S, Rasul A, et al. Synergetic effects of GOS and cu nanoparticles as prebiotics on biochemical and metabolic hormonal profile in alloxan induced diabetic rats model. Pak J Pharm Sci. 2020;33(3):1297-302.

26. Hadwan MH, Abed HN. Data supporting the spectrophotometric method for the estimation of catalase activity. Data Brief. 2016;6:194-9.

27. Petrica L, Gluhovschi C, Velciov S. Chronic kidney disease and the involvement of estrogen hormones in its pathogenesis and progression. Rom J Intern Med. 2012;50(2):135-44.

28. Basma AA, Zakaria Z, Latha LY, Sasidharan S. Antioxidant activity and phytochemical screening of the methanol extracts of Euphorbia hirta L. Asian Pac JTrop Dis. 2011;4(5):386-90 Basma AA, Zakaria Z, Latha LY, Sasidharan S. Antioxidant activity and phytochemical screening of the methanol extracts of Euphorbia hirta L. Asian Pac J Trop Dis. 2011;4(5):386-90.

29. Anwer T, Sharma M, Pillai KK, labal M. Effect of Withania somnifera on insulin sensitivity in non-insulin-dependent diabetes mellitus rats. Basic Clin Pharmacol Toxicol. 2008;102(6):498-503.

30. Bezerra RM, Ueno M, Silva MS, Tavares DQ, Carvalho CR, Saad MJ. A high fructose diet affects the early steps of insulin action in muscle and liver of rats. J Nutr. 2000;130(6):1531-5.

31. Teff KL, Elliott SS, Tschöp M, Kieffer TJ, Rader D, Heiman M, et al. Dietary fructose reduces circulating insulin and leptin, attenuates postprandial suppression of ghrelin, and increases triglycerides in women. J Clin Endocrinol Metab. 2004:89(6):2963-72.30.

32. Afshin A, Micha R, Khatibzadeh S, Mozaffarian D. Consumption of nuts and legumes and risk of incident ischemic heart disease, stroke, and diabetes: a systematic review and meta-analysis. Am J Clin Nutr. 2014;100(1):278-88

33. Nderitu AM, Dykes L, Awika JM, Minnaar A, Duodu KG. Phenolic composition and inhibitory effect against oxidative DNA damage of cooked cowpeas as affected by simulated in vitro gastrointestinal digestion. Food Chem. 2013;141(3):1763-71.

34. Xu JG, Tian CR, Hu QP, Luo JY, Wang XD, Tian XD. Dynamic changes in phenolic compounds and antioxidant activity in oats (Avena nuda L.) during steeping and germination. J Agric Food Chem. 2009;57(21):10392-8.

35. Roden $\mathrm{M}$, Shulman $\mathrm{Gl}$. The integrative biology of type 2 diabetes. Nature. 2019;576(7785):51-60

36. Ugochukwu N, Babady N. Antioxidant effects of Gongronema latifolium in hepatocytes of rat models of non-insulin dependent diabetes mellitus. Fitoterapia. 2002;73(7-8):612-8.

37. Taylor R, Agius L. The biochemistry of diabetes. Biochem J. 1988;250:62540 36. Wang $C$. The relationship between type 2 diabetes mellitus and related thyroid diseases. J Diabetes Res. 2013;2013.

38. Ogbonna S, Ezeani I. Risk factors of thyroid dysfunction in patients with type 2 diabetes mellitus. Front Endocrinol. 2019;10:440.

39. Swamy R, Kumar N, Srinivasa K, Manjunath G, Prasad Byrav D, Venkatesh G. Evaluation of hypothyroidism as a complication in type II diabetes mellitus. Biomed Res. 2012;23(2):170-2.

40. Parmar HS, Kar A. Antidiabetic potential of Citrus sinensis and Punica granatum peel extracts in alloxan treated male mice. Biofactors. 2007:31(1):17-24

41. Wannamethee SG, Tchernova J, Whincup P, Lowe GD, Kelly A, Rumley A, et al. Plasma leptin: associations with metabolic, inflammatory and haemostatic risk factors for cardiovascular disease. Atherosclerosis. 2007;191(2):418-26

42. McNeely MJ, Boyko EJ, Weigle DS, Shofer JB, Chessler SD, Leonnetti DL, et al. Association between baseline plasma leptin levels and subsequent development of diabetes in Japanese Americans. Diabetes Care. 1999;22(1):65-70

43. Söderberg S, Zimmet P, Tuomilehto J, Chitson P, Gareeboo H, Alberti K et al. Leptin predicts the development of diabetes in Mauritian men, but not women: a population-based study. Int J Obes. 2007;31(7):1126-33.

44. Welsh P, Murray HM, Buckley BM, De Craen AJ, Ford I, Jukema JW, et al. Leptin predicts diabetes but not cardiovascular disease: results from a large prospective study in an elderly population. Diabetes Care. 2009;32(2):308-10.

45. Cooper G, Willis A, Clark A, Turner R, Sim R, Reid K. Purification and characterization of a peptide from amyloid-rich pancreases of type 2 diabetic patients. Proc Natl Acad Sci. 1987;84(23):8628-32.

46. Zhang $X-X$, Pan Y-H, Huang Y-M, Zhao H-L. Neuroendocrine hormone amylin in diabetes. World J Diabetes. 2016;7(9):189.

47. Hrnciar J. Amylin as an additional possible pathogenic factor in NIDDM and the insulin resistance syndrome. Vnitr Lek. 1996;42(8):557-60.

48. Maurya AK, Tripathi S, Ahmed Z, Sahu RK. Antidiabetic and antihyperlipidemic effect of Euphorbia hirta in streptozotocin induced diabetic rats. Pharm Lett. 2012:4(2):703-7.

49. Maqsood S, Benjakul S, Abushelaibi A, Alam A. Phenolic compounds and plant phenolic extracts as natural antioxidants in prevention of lipid oxidation in seafood: a detailed review. Compr Rev Food Sci. 2014:13(6):1125-40.

50. Al-Nahdi AM, John A, Raza H. Cytoprotective effects of N-acetylcysteine on streptozotocin-induced oxidative stress and apoptosis in RIN-5F pancreatic $\beta$-cells. Cell Physiol Biochem. 2018;51 (1):201-16.

51. Ntimbane T, Mailhot G, Spahis S, Rabasa-Lhoret R, Kleme ML, Melloul D, et al. CFTR silencing in pancreatic $\beta$-cells reveals a functional impact on glucose-stimulated insulin secretion and oxidative stress response. Am J Physiol Endocrinol Metab. 2016;310(3):E200-12.

52. Al Nahdi AM, John A, Raza H. Elucidation of molecular mechanisms of streptozotocin-induced oxidative stress, apoptosis, and mitochondrial dysfunction in Rin-5F pancreatic $\beta$-cells. Oxidative Med Cell Longev. 2017:2017:1-15. https://doi.org/10.1155/2017/7054272 53. Sasikala S, Naidu MD. Evaluation of protective effect of Centella asiatica leaves on pancreas function in diabetic rats. Int J Herb Med. 2019;7(1):55-60.

53. Kim JH, Kang MJ, Choi HN, Jeong SM, Lee YM, Kim JI. Quercetin attenuates fasting and postprandial hyperglycemia in animal models of diabetes mellitus. Nutr Res Pract. 2011;5(2):107-11.

54. El-Sayed MI, Al-Massarani S, El Gamal A, El-Shaibany A, Al-Mahbashi HM. Mechanism of antidiabetic effects of Plicosepalus Acaciae flower in streptozotocin-induced type 2 diabetic rats, as complementary and alternative therapy. BMC Complement Med Ther. 2020;20(1):1-5.

55. Cignarella A, Bolego C. Mechanisms of estrogen protection in diabetes and metabolic disease. Horm Mol Biol Clin Invest. 2010:4(2):575-80.

\section{Publisher's Note}

Springer Nature remains neutral with regard to jurisdictional claims in published maps and institutional affiliations.

Ready to submit your research? Choose BMC and benefit from

- fast, convenient online submission

- thorough peer review by experienced researchers in your field

- rapid publication on acceptance

- support for research data, including large and complex data types

- gold Open Access which fosters wider collaboration and increased citations

- maximum visibility for your research: over 100M website views per year

At BMC, research is always in progress.

Learn more biomedcentral.com/submissions 